\title{
1: 65603007-65815197
}

National Cancer Institute

\section{Source}

National Cancer Institute. 1:65603007-65815197. NCI Thesaurus. Code C44987.

Physical location of LEPR_Gene 